\title{
Economic Order Quantity Model for Perishable Items Having Exponentially Increasing Demand
}

\author{
Sarbjit Singh (Corresponding author) \\ Institute of Management Technology, Nagpur, India \\ E-mail: sarbjitoberoi@gmail.com
}

Sayan Banerjee

Institute of Management Technology, Nagpur, India

Received: March 9, 2019

doi:10.5296/ijafr.v9i1.14476
Accepted: March 20, 2019 Published: March 31, 2019

URL: https://doi.org/10.5296/ijafr.v9i1.14476

\begin{abstract}
This study considers perishable items whose deterioration starts immediately after procurement with constant rate of deterioration, $\xi$. The goods considered in the paper are fast moving goods whose demand is increasing at a very rapid pace. Therefore, the demand has been considered as exponentially increasing demand. This study provides the buyer with a policy that aids them to decide their optimal order quantity considering the goods are perishable goods with exponentially increasing demand.
\end{abstract}

Keywords: Perishable items, Exponentially increasing demand, Economic Order Quantity (EOQ), Cycle time, Flow of inventory

\section{Introduction}

In the last two decades organizations are giving lot of importance to inventory management of perishable items. With increasing globalization and competition, organizations want optimal use of their resources. (Wilson, 1934, 116-128) was the first to work on the economic order quantity model. He proposed the basic EOQ model with ordering and holding cost. (Ghare and Schrader, 1963, 238-43) were first who studied and framed the model for an item with an exponentially decaying inventory. Since then researches on perishable goods have become very popular. (Shah \& Jaswal, 1977, 108-112) formulated a model considering a variable rate of deterioration with two parameter Weibull distribution. (Chung and Ting, 1994, 5392-5396) determined the replenishment schedules for deteriorating items with time proportional demand. 


\section{Mll Macrothink}

International Journal of Accounting and Financial Reporting

ISSN 2162-3082

2019, Vol. 9, No. 1

(Hariga and Benkherouf, 1994, 123-137) developed an inventory replenishment model for deteriorating items with exponentially varying demand. This work was extended by (Hargia, 1995, 2391-2401) to allow shortages. (S. P. Aggarwal \& C. K. Jaggi, 1995, 658-662) worked on ordering policies of deteriorating items under permissible delay in payment (Chakrabarti, $\mathrm{T}$. and Chaudhuri, K.S., 1997, 205-213) developed an EOQ model for deteriorating items with linear trend in demand and shortages in all cycle. (Bhunia, A. K. and M. Maiti, 1998, 997-1006) has formulated an inventory model for deteriorating items with finite rate of replenishment dependent on inventory level.

(Chang H-Y and Dye C-Y, 1999, 1176-1182) analyzed the scenario where demand is a timecontinuous function and items deteriorate at a constant rate with partial backlogging. (Peter Chu and Patrick S. Chen, 2002, 1827-1842) showed the inventory carrying cost is in the proportion to the cost of deteriorated items, then offered a formulated approximated solution. (Miguel F. Anjos, Russell C. H. Cheng and Christine S. M. Currie, 2005, 246-254) proposed optimal pricing policies for perishable products. (Kuo-Lung Hou, 2006,463-474) developed an inventory model for deteriorating items with stock-dependent consumption rate and shortages under inflation and time discounting. (Jian Li, T. C. Edwin Cheng and Shouyang Wang, 2007, 331-38) provided studied postponement strategy for perishable items by Economic Order Quantity -based models. (Jui-Jung Liao, 2007, 1690-1699) had explored the inventory replenishment policy for deteriorating items, in which the supplier provides a permissible delay to the purchaser if the order quantity is greater than or equal to a predetermined quantity. (Yu-Chung Tsao and Guo- Ji Sheen, 2008, 3562-3568) had studied the problem of dynamic pricing, promotion and replenishment for a deteriorating item subject to the supplier's trade credit and retailer's promotional effort. (Roy and Choudhari, 2009, 325-346) developed two production inventory models for deteriorating items when the demand rate depends on the instantaneous inventory level. (Shah and Shukla, 2009, 421-428) formulated a deterministic inventory model in which product is subject to constant deterioration and shortages are allowed. (Jie Min, Yong-Wu Zhou and Ju Zhao, 2010, 3273-3285) had developed a lot-sizing model for deteriorating items with a current-stock-dependent demand and delay in payments. (Gour Chandra Mahata, 2012, 3527-3550) had investigated the optimal retailer's replenishment decisions for deteriorating items under two levels of trade credit policy to reflect supply chain management within the economic production quantity (EPQ) framework. Lio, Chung and Huang, 2013, 557-565) had designed recently a two-warehouse inventory model for deteriorating items when the supplier offers the retailer a delay period and in turn the retailer provides a delay period to their customers. (Bhanu Priya Dash, Trailokyanath Singh, Hadibandhu Pattnayak, 2014, 1-7) developed an inventory model for perishable goods with exponential decreasing demand and time dependent holding cost.

(Ata and Nematolla, 2014, 93-109) formulated a model for deteriorating items with back-ordering and financial considerations. (Jaggi, C. K., L. E. Cardenas, Barron S. Tiwari \& A. A. Shafi, 2017, 390-412) worked on inventory model for deteriorating items with imperfect quality under the conditions of permissible delay in payment (Singh Sarbjit, 2017, 2152-2158 ) obtained an optimal ordering policy for deteriorating items having constant demand. 


\section{Macrothink}

International Journal of Accounting and Financial Reporting

ISSN 2162-3082

2019, Vol. 9, No. 1

In this paper an inventory policy has been derived for deteriorating products with constant deterioration rate and exponentially increasing demand which was not considered in the earlier models, this study provides the formula by which the wholesalers/retailers can plan their inventory cycle and optimal order quantity. The point of minima has been obtained which aids in providing optimal ordering cost. The proposed model can be converted into constant demand model by considering $\alpha=0$. The numerical illustrations have been provided to support the validity of the model.

\section{Notation and Assumptions}

The following notations and assumptions are used throughout this paper

$\mathrm{A}_{\mathrm{D}}$ : Amount of items deteriorated during a cycle time, $\mathrm{T}$

$\xi$ : Deterioration rate, a fraction of the on-hand inventory

p: The unit price per item (dollars/unit)

S: The ordering cost (dollars/order)

$\mathrm{Xe}^{\alpha}$ : The demand rate (units per unit time)

$\mathrm{T}_{\mathrm{C}}$ : Inventory order cycle time

h: Holding cost (percent of the price per unit per year)

HC: Total Holding cost (dollars per Cycle)

\subsection{Assumptions}

1) Shortages are not allowed to occur.

2) Replenishment rate is infinite and the lead time is negligible.

3) The deterioration of items starts immediately after procurement

4) The deterioration rate is constant; a constant fraction $\theta(0 \leq \theta \leq 1)$ of inventory deteriorates per unit time.

5) There is no repair or replenishment of the deteriorated items during the inventory cycle.

6) L is the length of the finite planning horizon.

7) The demand is increasing exponentially

\section{Model Formulation}

Taking into consideration the above assumptions with exponentially increasing demand, the inventory system goes like this: the depletion of the inventory occurs due to demand (supply) and deterioration both and the inventory at any time $\mathrm{t}$ is given by

$$
\frac{d I(t)}{d t}+\xi I(t)=-\lambda e^{\alpha t}, \quad 0 \leq t \leq T_{c}
$$


Solving above differential equation, we get $\mathrm{I}(\mathrm{t})$ during the time period $\left(0 \leq t \leq T_{c}\right)$

$$
I(t)=-\frac{\lambda}{(\xi+\alpha)} e^{\alpha t}+C e^{-\theta t}, \quad 0 \leq t \leq T_{c}
$$

Using the condition, at the time, $t=T_{c}$ i.e. at the end of a cycle, $\mathrm{I}(\mathrm{T})=0$, which gives

$$
I(t)=\frac{\lambda}{(\xi+\alpha)}\left(e^{(\xi+\alpha) T_{c}}-e^{\alpha t}\right) 0 \leq t \leq T_{c}
$$

At time $\mathrm{t}=0$, when the order is placed and received, assuming lead as zero i.e. starting of the inventory cycle, $\mathrm{I}(0)=I_{0}$ (Initial Inventory) and equation (3) gives the ordering quantity as

$$
I_{0}=\frac{\lambda}{(\xi+\alpha)}\left(e^{(\xi+\alpha) T_{c}}-1\right)
$$

Initial ordered quantity would be dependent on both exponentially increasing demand and deterioration rate. Thus, the number of items deteriorated in each cycle would be given by

$$
\begin{gathered}
T_{D}=I_{0}-\int_{0}^{T_{c}} \lambda e^{\alpha t} d t \\
T_{D}=\frac{\lambda}{(\xi+\alpha)}\left(e^{(\xi+\alpha) T_{c}}-1\right)-\frac{\lambda}{\alpha}\left(e^{\alpha T_{c}}-1\right)
\end{gathered}
$$

The deterioration cost is given by

$$
c * D_{T}=p\left(\frac{\lambda}{(\xi+\alpha)}\left(e^{(\xi+\alpha) T_{c}}-1\right)-\frac{\lambda}{\alpha}\left(e^{\alpha T_{c}}-1\right)\right)
$$

The total variable cost per cycle would be the sum of ordering, holding and deterioration cost

$$
C_{V T}=S+\frac{\lambda h p}{(\xi+\alpha)}\left(e^{(\xi+\lambda) T_{c}}-1\right)+p\left(\frac{\lambda}{(\xi+\alpha)}\left(e^{(\xi+\alpha) T_{c}}-1\right)-\frac{\lambda}{\alpha}\left(e^{\alpha T_{c}}-1\right)\right)
$$

In real life, the rate of increase and deterioration is very low. Hence, using Taylor series expansion for the exponential term, we have

$$
e^{(\xi+\alpha) T_{C}} \approx 1+(\xi+\alpha) T_{C}+(\xi+\alpha)^{2} \frac{T_{C}^{2}}{2}
$$




$$
\begin{gathered}
e^{\alpha T} \approx 1+\alpha T_{C}+\frac{\alpha^{2} T_{C}{ }^{2}}{2} \\
C_{V T}=S+\lambda P h T\left(1+\frac{(\theta+\alpha)}{2} T\right)+c D \frac{T^{2}}{2}
\end{gathered}
$$

Total Variable cost is given by $C_{T}=\frac{C_{V T}}{T}$

$$
C_{T}=\frac{S}{T_{C}}+\lambda p h\left(1+\frac{(\xi+\alpha)}{2} T_{C}\right)+\frac{p \lambda T_{C}}{2}
$$

Using principle of maxima and minima, it can prove that the equation for the total cost is convex and helps in reducing the total inventory cost.

The proposed model can be converted into constant demand taking $\alpha=0$ and also it can be converted into the Classical EOQ model by considering non deteriorating items.

\section{Numerical Illustrations}

Considering $\mathrm{S}=\$ 500, \mathrm{p}=\$ 20, \lambda=1,000, \mathrm{~h}=0.1, \quad \xi=0.1$ and $\alpha=.05$

The cycle time comes out to be 31.8 days (approx.) and total variable cost per cycle to the company is $\$ 199$ and total variable cost is $\$ 2388$

\section{Conclusion}

In this paper an economic order quantity model has been formulated that aids purchasers in deciding their cycle time and optimal inventory flow for perishable goods. This study can help retailers/ wholesalers in minimizing their operating costs for items whose demand is increasing exponentially. Although, demand increasing exponentially for longer period is not possible but for smaller period it can happen that demand for some goods increases exponentially and then stabilizes. This study provides an optimal inventory policy for deteriorating items whose demand is increasing exponentially. The numerical illustrations has been provided to demonstrate the use of the model.

\section{References}

Aggarwal, S. P., \& Jaggi, C. K. (1995). Ordering policies of deteriorating items under permissible delay in payment. Journal of Operational Research Society, 46, 658-662.

Anjos, M. F., Cheng, R. C. H., \& Currie, C. S. M. (2005). Optimal pricing policies for perishable products. European Journal of Operational Research, 166(1), 246-254. 


\section{$\triangle 1$ Macrothink}

International Journal of Accounting and Financial Reporting

ISSN 2162-3082 2019, Vol. 9, No. 1

Bhunia, A. K., \& Maiti, M. (1998). Deterministic inventory model for deteriorating items with finite rate of replenishment dependent on inventory level. Computers and Operations Research, 25(11), 997-1006.

Chakrabarti, T., \& Chaudhuri, K. S. (1997). An EOQ model for deteriorating items with linear trend in demand and shortages in all cycle. International Journal of Production Economics, 49, 205-213.

Chandra, M. G. (2012). An EPQ inventory model for exponentially deteriorating items under retail partial trade policy in supply chain. Experts Systems with Application, 39(3), 3537-3550.

Chang, H.-Y., \& Dye, C.-Y. (1999). An EOQ for deteriorating items with time varying demand and partial backlogging. Journal of Operational Research Society, 50, 1176-1182.

Chu, P., \& Patrick, S. H. (2002). A note on inventory replenishment policies for deteriorating items in an exponentially declining market. Computers and Operations Research, 29(13), $1827-1842$.

Chung, K. J., \& Ting, P. S. (1994). On replenishment schedule for deteriorating items with time proportional demand. Production Planning and Control, 5, 392-396.

Dash, B. P., Singh, T., \& Pattnayak, H. (2014). An Inventory Model for Deteriorating Items with Exponential Declining Demand and Time-Varying Holding Cost. American Journal of Operations Research, 4, 1-7.

Ghare, P. M., \& Schrader, G. P. (1963). A model for exponential decaying inventory. Journal of Industrial Engineering, 14(3), 238-43

Hariga, M. (1995). Lot sizing models for deteriorating items with time dependent demand. International Journal of Systems Sciences, 26(7), 2391-2401.

Hariga, M. A., \& Benkherouf, L. (1994). Optimal and heuristic inventory replenishment models for deteriorating Items with Exponential time-varying demand. European Journal of Operational Research, 79,123-137.

Hou, K.-L. (2006). An inventory model for deteriorating items with stock-dependent consumption rate and shortages under inflation and time discounting. European Journal of Operational Research, 168, 463-474.

Jaggi, C. K., Cardenas-Barron, L. E., Tiwari, S., \& Shafi, A. A. (2017). Two warehouse inventory model for deteriorating items with imperfect quality under the conditions of permissible delay in payment. Scientia Iranica E., 24(1), 390-412.

Li, J., Cheng, T. C., \& Wang, S. Y. (2007). Analysis of postponement strategy for perishable items by EOQ-based models. International Journal of Production Economics, 107(1), 31-38.

Liao, J. J. (2007). A note on an EOQ for deteriorating items under supplier credit linked to order quantity. Applied Mathematical Modelling, 31, 1690-1699. 


\section{MlMacrothink}

International Journal of Accounting and Financial Reporting

ISSN 2162-3082

Liao, J.-J., Chung, K.-J., \& Huang, K.-N. (2013). A deterministic inventory model for deteriorating items with two warehouses and trade credit in a supply chain system. International Journal of Production Economics, 146(2), 557-565.

Roy, T., \& Chaudhari, K. S. (2009). A production inventory model under stock-dependent demand, Weibull distribution deterioration and shortage. International Federation Operational Research Society, 16(3), 325-346.

Sarbjit, S. (2017). Optimal ordering policy for deteriorating items having constant demand and deterioration rate. Theoretical Economics Letters, 7, 2152-2158.

Shah, N. H., \& Shukla, K. T. (2009). Deteriorating Inventory Model for waiting time Partial Backlogging. Applied Mathematical Sciences, 3(9), 421-428.

Shah, Y. K., \& Jaiswal, M. C. (1977). An order level lot size inventory for deteriorating items. AIIE Transactions, 9(2), 108-12.

Taleizadeh, A. A., \& Nematolla, M. (2014). An inventory control problem for deteriorating items with back-ordering and financial considerations. Applied Mathematical Modelling, 38(1), 93-109.

Tsao, Y.-C., \& Sheen, G.-J. (2008). Dynamic pricing, promotion and replenishment policies for a deteriorating item under permissible delay in payments. Computers and Operations Research, 35(11), 3562-3580.

Wilson, R. H. (1934). A scientific routine for stock control. Harvard Business Review, 13, 116-128.

Zhou, M. J., Wu, Y., \& Ju, Z. (2010). An inventory model for deteriorating items under stock-dependent demand and two level trade credit. Applied Mathematical Modelling, 34(11), 3273-3285.

\section{Copyright Disclaimer}

Copyright for this article is retained by the author(s), with first publication rights granted to the journal.

This is an open-access article distributed under the terms and conditions of the Creative Commons Attribution license (http://creativecommons.org/licenses/by/4.0/) 